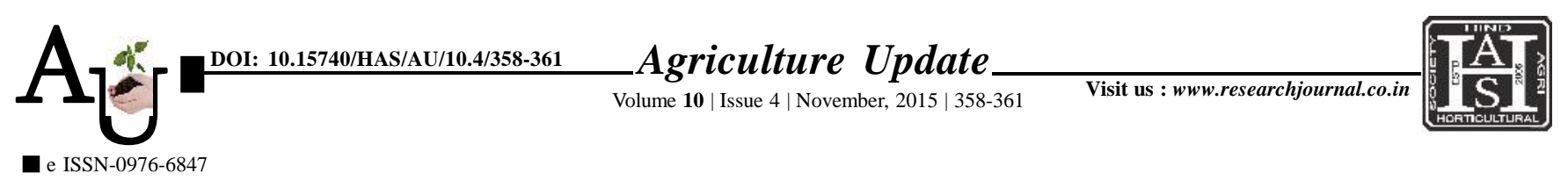

\title{
A Case Studx: Impact of front line demonstrations on productivity of carrot cV. PUSA RUDHIRA in Dholpur district of Eastern Rajasthan
}

\section{DILIP SINGH}

Article Chronicle:

Received :

20.08.2015;

Accepted :

30.10 .2015

\section{KEY WORDS:}

Front line demonstration, Local check, Carrot, Technology, Yield

Author for correspondence :

\section{DILIP SINGH}

Krishi Vigyan Kendra (S.K.N.A.U.), Kumher, BHARATPUR

(RAJASTHAN) INDIA

Email: dilipsingh.1970@ rediffmail.com
SUMMARY : The Present study was carried out at Dholpur district of Eastern Rajasthan during 201213. Carrot is one of the most important vegetable crops of the country. The development of the Agriculture is primarily depends on the application of the scientific technologies by making the best use of available resources. One of the major constraints of traditional carrot farming is low productivity because of non-adoption of advanced technologies. To increase the production, productivity and quality of agricultural produce, front line demonstrations are being conducted at various farmer's field. All the recommended practices were provided to the selected farmers. The data related to the cost of cultivation, production, productivity, gross return and net return were collected as per schedule and analyzed. Result of the present study revealed that the high yielding variety of carrot Pusa Rudhira recorded the higher yield ( $275.71 \mathrm{q} / \mathrm{ha}$ ) as compared to local check ( $232.14 \mathrm{q} / \mathrm{ha})$ traditionally grown by the farmers. The percentage increase in the yield over local check was 18.74 per cent.The technology gap in terms of productivity $(43.57 \mathrm{q} / \mathrm{ha}$.) were computed. The technology index values $(16.45 \%)$ was recorded.The result of the study indicated the gap existed in the potential yield and demonstration yield is due to soil fertility and weather conditions. By conducting front line demonstration (FLDs) of proven technologies, yield potential of carrot can be increased upto great extent. This will substantially increase the income as well as the livelihood of the farming community.

How to cite this article : Singh, Dilip (2015). Impact of front line demonstrations on productivity of carrot $\mathrm{cv}$. PUSA RUDHIRA in Dholpur district of Eastern Rajasthan. Agric. Update, 10(4): 358-361. 